Article

\title{
Not So Much about Informality: Emergent Challenges for Urban Planning and Design Education
}

\author{
Paulo Silva \\ Department of Social, Political and Territorial Sciences, University of Aveiro, 3810-193 Aveiro, Portugal; \\ paulosilva@ua.pt
}

Received: 14 October 2019; Accepted: 1 April 2020; Published: 14 October 2020

\begin{abstract}
This paper addresses the challenges faced by planning and design education programmes when focusing on more sustainable ways of dealing with global changes. While the dominant discourse addresses the fact that planning programmes discuss the Global South through the lens of planning theory and practice from the Global North, the proposal is to shift the debate and recognise that, from a complexity perspective, planning problems are not so different from region to region. The argument is that, although the theory has moved on, when discussing conceptual aspects of planning, spatial planning practice is still focused on objects rather than the relationship between them (be they buildings, streets, neighbourhoods or even cities). Assuming that urban territories are not objects and do not develop in a linear way, but rather evolve, the proposal is to reflect on how planning and design education addresses urban evolution. This paper suggests a revision of planning and design approaches to informality, given the participation in recent years of a joint studio in Bandung, Indonesia. The alternative perspective offered here involves a re-examination of concepts and deconstruction of dichotomies. The main findings rely on the interpretation of formalisation processes (in the Global North) through the lens of complexity theory, which has facilitated understanding of today's informal settlements (in the Global South). It suggests the deconstruction of dichotomies, such as informal versus formal, thus, positing the need for a major shift on planning and design rules that focus less on objects and more on the relationship between them.
\end{abstract}

Keywords: Sustainable Development Goals; planning education; planning challenges; informal settlements; Portugal; Bandung; urban design; complexity

\section{Introduction}

The main purpose of this paper is to reflect on the way planning and design education deals with the emerging understanding of cities as part of multi-scalar urban systems, resulting in rapid changes [1]. Although complexity is becoming part of planning theory debate and is embedded in urban policy design, there is little sign of how this affects planning practice. Moreover, there is a medium to long-term need to change at the planning and design education level. To achieve this goal, the integration of planning and complexity theory, as well as planning education and planning practice, offers new insights to the planning debate [2].

In this context, informality is important to integrate both planning and complexity theory and planning education for one main reason: Informality, by its nature, establishes a different relationship with planning systems, and its widespread nature [3] creates an opportunity to innovate, in terms of planning practice. With regard to planning education, it allows inequality, water and sanitation scarcity to be addressed, as well as poor housing supply. Informality as a condition associated with the occupation of less advantaged urban territories also involves increasing vulnerabilities regarding either technological risks, due to the vicinity of infrastructures [4], or natural risks [5], due to climate change. For this reason, there is a greater need for sustainable ways of addressing territorial issues. 
However, looking back at past solutions, eviction and the construction of massive social housing blocks proved to be unsustainable [6]. Despite major investments in affordable public housing, social aspects have been neglected, the economics questioned from a financial perspective (due to continuous public investments), while environmental impact seems negligible.

When referring to the reduction of spatial disparities, informality is one of the critical spatial issues that need to be addressed. In human terms, the impact of informal settlements is clear, if related to the social satisfaction of their residents [7]. It is not possible to talk of successful formalisation of informal settlements without mentioning sustainability, in terms of long-term social benefits and spatial integration [8]. According to UN records, in the 21st century, over one billion people live in informal settlements. That said, in terms of spatial segregation, the numbers are even larger if we include those affected by demolition/relocation that ignores criteria of social integration, moving communities to more remote areas or keeping them in situ, replacing housing typologies without considering social amenities and increasing or replacing old spatial segregations-between formal and informal city-with new ones-between ex-informal or formal and formal. If the former is typically associated with what is currently designated as the Global South, the latter also exists in the Global North. Additionally, when spatial segregation diminishes, this is not a result of formalisation of informal settlements per se, but rather due to policies and planning measures implemented at a higher level.

Relationships between urban elements have been widely discussed since the 1960s, [9] highlighting alternatives to classical zoning techniques, albeit with a limited application in practice [10]. Mixing functions, instead of spatial zoning segregation, and combining different hierarchy levels were "new features" that broke modernistic concepts of functional segregation. While planning theory translated this into the concept of mixed-use in the formal city context, and planning practice applied it to public space levels [11], a broader application of the approach (mixed-use) to both the formal and informal city is still rare. Assuming that urban territories are not objects that develop in a linear way, but rather things that evolve [12], the proposal is to reflect on how planning and design education can address urban evolution.

As complex as urban systems are [13], this paper adopts concepts found in complexity theory. Through the lens of complexity, for any system to evolve, balance is required, which leads to two main ideas. The first is one of dynamics-a system is not static, but the result of a sum of multiple interactions. The second idea is dependent on the first: These multiple interactions involve a range of agents and relationships moving in opposite directions and at various levels. This is the condition stability relies upon, preventing systems from falling into chaos or stagnation. Too many dynamics can generate chaos [14] and destruction-many cities disappeared due to the devastation caused by wars; however, it is also true that entire cities disappeared, due to stagnation (e.g., fortified cities along national borders, which lost their purpose without finding a replacement). When it comes to contemporary urban settings, high degradation levels (a step towards chaos) can be found in both formal and informal contexts: Social housing blocks (formal city) and slums (informal city) can reach equal degrees of dereliction to the point that any improvements are impossible to implement.

In addition, urban systems generate a multiplicity of interactions, sometimes perceived as a single move. However, they correspond to multiple moves converging in the same direction [15] as a response to stimulus and allow adaptation. Change can be the result of adaptation, due to interaction between stable and dynamic elements. In complexity theory, this defines a hierarchy. Unlike the normal understanding of hierarchy in social systems (power relations), it relates to stability and dynamics: The former is considered to characterise the top of a system's hierarchy, and the latter the bottom. This allows urban developments to be understood beyond the confines of power relationships, and contribute to more sustainable city development.

This paper argues that such complexity is incompatible with dichotomous visions of city planning, such as formal versus informal, or bottom-up movements versus top-down. Based on a regulatory vision of planning, the dichotomy between formal and informal narrows the interpretation of people's 
personal needs [16] and hinders better planning tools. On the one hand, modernist visions of planning tend to create overly-stable settings, generated by very top-down, regulated spaces, with no room for unexpected social moves and dynamics. On the other hand, what some authors call a "bottom up" city runs the risk of generating overly-dynamic settings, excessively geared to individual and private needs, while limiting the ability to cater to collective and public aspirations. As an alternative to this "bottom-up" scenario, some successful formalisation processes of informal neighbourhoods appear to be more the result of a combination of bottom-up and top-down initiatives, with a strong experimental spirit, involving informal settlements and planning institutions [17,18].

In times of new spatial planning challenges, education and training become crucial, implying the search for new approaches and concepts. In this paper, the concept of sustainability relates to the fact that planning and design can have a positive impact on achieving durable social, economic, and environmental solutions. When it comes to planning and design education, there is another issue. Informality often divides the world into two global blocks: The wealthy, developed and "informality-free" North, which is also home to the most prestigious planning and design teaching institutions, and the developing South, which has most informal settlements, and many fewer planning and design schools [19]. Moreover, disparities between the two parts are even greater if we consider that many planning and design schools in the Global South tend to replicate programmes and teaching methodologies from the Global North [20].

The purpose of this paper is to combine teaching experiences in the Global North, with the outcomes of a joint studio (the University of Sydney and Institut Teknologi Bandung) that has been operating in Southeast Asia since 2015, focussing on an informal settlement in the city of Bandung. The combination of experiences with regard to the Global North and Global South was crucial to achieving this objective: From the Global North, this paper uses the analysis of informal settlement formalisation processes. Like other Southern European countries, Portugal is relevant as it successfully formalised informal settlements, but without dealing with their metropolitan integration [4]. The focus on informal settlements in Bandung, Indonesia, is relevant on a broader scale (the Asian-Pacific Region), representing part of the Global South. Between 2016 and 2019, during each edition of the joint studio, which involved ten days of fieldwork, the author interacted with students while they undertook site visits to the study area, meeting Institut Teknologi Bandung (ITB) colleagues and academics, as well as local facilitators (students or former ITB students) and local leaders [21]. In addition, the programme allowed for contextualisation of policy implementation in kampongs in Indonesia, either acknowledging national programmes, such as the former Kampong Improvement Programme (KIP) and the zero slum programme KOTAKU [22], or local planning policies and urban design approaches.

The next sections will address informality through the lens of complexity. Two sections will follow, which focus on informality in the Global North and Global South, respectively. The paper discusses possible changes to planning and design education programmes, while conclusions highlight final thoughts on how learning from informality using the complexity perspective can contribute to different teaching approaches (not only regarding informality, but also in terms of general planning and design topics).

\section{Planning and Design in a World in Transition between Colonial and Mega-Cities}

Planning evolved as a discipline to deal with development problems in a world dominated by new nations and old colonial empires-in North America and Europe. This geo-political situation reached a tipping point after the Second World War, when African and Asian territories became independent nations, involving different economic impacts and radical rearrangements following the end of the colonial order. Nothing of this occurred without significant territorial changes. However, planners continued planning the new urban world from a North West perspective, imposing its models and urban icons [23].

The advent of the welfare state crisis in the 1960s and the oil crisis in the 1970s led to more shared responsibilities between public and private sectors, generating new forms of governance. By the 
1980s, changing conditions made this a reality. In the 1990s, this dynamic led to a globalisation of the economy, due mainly to the development of new communication technologies. A Pandora's box of new possibilities had been opened, one of which was the decentralisation of the workforce, generating the rapid growth of cities in former colonies. There were also new risks, with weaker emergent public structures in new countries having to supply infrastructures and other basic needs to new urban populations. A new world with new challenges emerged, caused by the radical rearrangements of productive structures at a global level, with rural-urban migrations on a national scale in former colonies and the rise of mega-cities, mainly in Africa and Asia. Can planning meet these new challenges? —asks Alterman in a paper where she highlights the professional challenge beyond the discipline: "We will have to learn how to transfer knowledge across national and continental borders in a manner that would fit local needs" ([24], p. 11).

The advent of globalisation and new spatial challenges in the Global South occurs in a world still dominated by European and North American planning education institutions, which train planners worldwide. This Global North slant is well illustrated by comparing the weight of the Association of European Schools of Planning (AESOP) and Association of Collegiate Schools of Planning (ACSP) with the Asian Planning Schools Association (APSA) and Association of African Planning Schools (AAPS). The dominance of the Global North is clear. Looking at the make-up of the Global Planning Education Associations Network (GPEAN), it is dominated by AESOP-with 173 school members, mainly European [25] and ACSP — with 127 school members, mainly from the US [26] in comparison with APSA—with 58 school members, all from Asia [27] and AAPS—-with 54 school members, all from Africa [28].

Planners must now deal with global trends, such as mega-cities, of which informal settlements are an important part. In that sense, representations of space are always intentional. In the context of planning, architecture and design, cities can be subject to multiple meanings-urban form can be more than an object over a background. According to Tatarkiewicz, it is at least four more things [29]. Policies, while sectorial, risk "thematising" territories; for instance, urban regeneration can be translated into many different contexts, far beyond areas of historical value (such as historical centres) or socially deprived areas within the state sphere, such as social housing areas; it also includes informal settlements and brownfields, where policy integration is still missing.

\section{The Complex Path of Informality}

Successful stories of formalising informal settlements do exist, be they water and sanitation [30], land tenure [31], participatory process [32], risk management [33] or inclusiveness of spaces [34]. However, solutions are incomparably less evident than the growth of new informal settlements worldwide [35]. Are planners and designers doing enough? Although planners and designers are part of multiple workable solutions, the answer to this question is not a simple yes or no. There is a need to prepare future generations of planners and urban designers for new and unexpected events $[20,36,37]$ This is an important debate because it is not clear what can be delivered regarding new contexts and ways of addressing informal settlements, such as physical transformations and social empowerment, radical evictions and soft upgrading, rigid norms and flexible guidelines. In such a heterogeneous environment, planners and designers are looking for their places in the formalisation processes.

How did urban planning evolve in relation to informality? Worldwide concerns regarding urban development go back to the 1970s with the Habitat I forum organised by the United Nations (Vancouver, 1976). In the 1980s, informal settlements led to a new generation of urban policies. While in Europe this was a problem of the south (mainly in Portugal, Spain, Italy and Greece), globally-speaking, experiments were taking place. Most of these were in Latin America, which, in turn, started to inspire other places, such as South African cities [38]. Although informality was increasing in some Portuguese-speaking African countries (mainly Angola and Mozambique), this was still not a major issue, as these countries had to deal with worse problems, such as civil war. Following Habitat III, three key words arose from SDG 11-inclusive, resilient, and sustainable. Therefore, as informal settlements 
are part of urban systems, it is exceedingly difficult to separate them from formal areas. For that reason, studies focus on the relationship between formal and informal areas in cities using planning as a tool for integration.

The relentless march of informality can be seen in the figures. The number of residents in informal settlements has already exceeded one billion, and the social, environmental, and economic problems associated with this kind of settlement are regularly found on international agendas. While the United Nations has recently addressed informality as a challenge for inclusiveness in cities in the Global South, it also acknowledges the experience of dealing with informality in Global North countries, like Portugal, Spain, Greece and Italy [39], as well as underlining the role of self-organising and co-evolutionary processes [40]. Reference to these processes is an institutional recognition of the complexity of these contexts at the highest level.

There is one main reason for the strong connection between complexity and informality. Since there is no top-down regulation, informal settlements depend much more on individual decisions. Based on those individual decisions, change can appear very unexpectedly [41] through self-organising processes, leading to temporary adaptation (resilience, as found in SDGs), but also to permanent adaptation (evolution and even co-evolution). When it comes to informality, the UN says there is a need to draw attention to innovative methods exploring adaptation (instead of eviction) and self-organising solutions. In order to discuss informality, it is assumed that it is part of the urban fabric, and as such, part of complex, adaptive and hierarchical systems [42-44], in which power relations matter. However, it is also about how stable (top of the hierarchy) or how dynamic (bottom of the hierarchy) elements of the systems are. Planning institutions are more stable, and therefore, form part of the top of the hierarchy, but they can "move" temporarily to the bottom and become dynamic and adaptive, as selective pressures can occur.

\section{Why Do Planners Need a New Mindset to Face Global Complex Challenges?}

In this paper, planning institutions combine regulatory tools (norms and rules) and executive bodies (such as agencies and organisations). The position of planning institutions is the result of constant reinforcement of one party by the other party. Norms and rules are the (most) stable part of the system, while organisations are the (most) dynamic section. This applies to most planning systems in the world. Sometimes planning institutions are too stable, and unable to adapt to new circumstances [45]. When planning institutions and informality are too discrepant, the main role of planning rules (the stable part of planning institutions) is lost, since those rules are no longer able to harmonise interactions between agents at different levels. If they are not considered illegal, per se, their relationship with the law is somewhat unpredictable [46]. Bridging this gap between formality and informality requires change. Often, change is seen as necessary from the informality side, to adapt to formality. Some research-based on successful cases of formalisation highlight the fact that informality requires adaptation to meet legal standards, but, at the same time, formality (and planning institutions in particular) also have to adapt. When this adaptation is permanent and interdependent, this may refer to co-evolution between planning institutions and informality. When this co-evolution has a broader impact, not only on how planning institutions and informal settlements interact, but also on planning institutions' ability to learn and replicate those lessons to other contexts, then we can say that, by exposing planning institutions to informality, change is promoted at higher levels [47]. Their impact is multi-level, since it affects planning and design practices, as well as feeding innovative approaches, in terms of planning and design theory.

Trigger moments are necessary for the first stages of co-evolution to happen, but those can take a lifetime, when it comes to larger and more complex settings. When they correspond to pressures on institutions, they challenge their well-known rigidity, contributing to more malleable behaviours. Awareness of such processes is missing from planners' and designers' education curricula. In order to support theory and prepare students for future challenges, examining case studies (such as Lebak Siliwang, which will be addressed later) is an effective way of studying less well-known realities more 
quickly and in greater depth, such as informal ones, where built environments can reach a higher level of complexity [48].

\section{The Global North}

Nowadays, the world sees Europe as an "informal settlement-free continent", despite the 50 million residents in informal settlements in the eastern region [49]. Nevertheless, among the academic community, a new generation of planners is starting to draw attention to informality in Europe, learning from the Global South [50] or unexpectedly focusing on countries, such as Britain, Belgium, Poland [51]. Although statistically irrelevant, when compared with the rest of the world's rampant informal urbanisation, they represent a new niche of informality. Work from a new generation of researchers is drawing new attention to informality as part of the European landscape. An even less explored side of informality is the one that combines real estate funds, tax havens, and golden visas, which can be called white-collar informality. The different grades of informality are just evidence that, despite the efforts to deal with informality, it is still present in the Global North, in relation to gaps left by planning law.

The Global North developed at least three patterns of interaction between planning institutions and informality. The first of these patterns is rooted in eviction. It became the most effective way of dealing with informality, characterising the early efforts of how the authorities dealt with slums as a result of the industrial revolution-bulldozer phase [6]. The Global South is rediscovering this "old" way of dealing with informality, and again, expects negative social impacts from these processes [52]. The second pattern corresponds to the design of planning rules to include informality "without losing face" through "planning games" [53]. All over Europe, law-amendments, amnesties, temporary windows of legalisation have occurred (as this paper is being prepared, a new law has been published in Andalusia, Spain, potentially allowing the legalisation of around 300,000 houses in this autonomous community). The third pattern is one of planning systems co-evolving with informality and from that interaction, learning how to improve planning rules while encouraging an upgrade of informal occupations [54].

The political perspective approaches informality as an expression of low housing standards [55], poverty [56], and lack of social rights [57]; and dictatorships ignore or underestimate the importance of this [58]. During the 1970s, informality started to be addressed in Europe, leading to novel approaches. In political terms, recently-established democracies in Southern European countries allowed this shift. Portugal, Spain, and Greece started to deal with informality, followed closely by countries like Italy [40]. Although major efforts (in technical and financial terms) were successfully applied to the formalisation of informal settlements, little of this was translated into planning and design education. In Portugal, informality is no longer an issue in terms of housing scarcity, and now, like other Southern European countries, it is reaching the end of the "informality chain", seeking new planning approaches $[59,60]$.

Between the 1960s and 1990s, "clandestine" was the word used to describe informal settlements, combined with either the word "occupation" or "construction". With the end of the dictatorship in 1974 and the advent of democracy, these became better known as "bairros clandestinos". By the end of the 1990s, which coincided with a successful shift in dealing with informality, the term "illegal" became the official designation.

One of the first Portuguese universities to offer planning and design programmes was the University of Aveiro. It started by launching the first BSc programme in regional and urban planning in 1983, based on environmental priorities (1983-2007). In the early 2000s, the programme ended, due to the Bologna reform and a master's programme was created. Until 1983, planning and design programmes were the concern of engineering and architecture faculties (to be joined later in the 1990s by geography departments), in the shape of post-graduate or master's programmes. While the number of planning programmes was increasing, informality became less of a problem because of the historical tipping point that saw Portugal join the European Union in 1986. Environment and planning became 
two key points on the new member's agenda. Although informality was related to both, it never developed as a discipline within planning and design programmes.

By this time, Portuguese cities were partially made up of slums built on public land or/and illegally built private homes on illegally parcelled private land. This reached a peak in the 1980s, when over than $10 \%$ of the metropolitan population of Lisbon was living in this kind of space [54]. The Portuguese planning community (made up of many civil engineers and architects trained abroad) shared their concerns about this "Southern European stigma" with colleagues from Spain, Italy, and Greece. At the same time, there were exchanges with colleagues from Brazil; however, this was a highly politicised relationship and always subject to the country's political swings. By this time, slums in former Portuguese colonies were not considered a major problem, although there were already huge migratory movements to main cities, due to post-independence civil wars (especially in Angola and Mozambique).

Today "informality" is part of the Portuguese lexicon for external consumption and a general term used to discuss this issue with the international community. The term "illegal" has prevailed over the last two decades in domestic contexts, particularly in the legal framework, when discussing informal settlements. Dealing with informality by experimenting with different solutions and encouraging long-term relations and close connections among stakeholders seems to have been the secret of its success-from exponential numbers in the 1980s to the current near-zero levels. Interpretations of its complexity helped not only to decipher the improvements caused by self-organising, evolutionary and co-evolutionary processes, but also to shed light on the benefits to the general planning framework. Table 1 demonstrates the diversity of approaches that informal dynamics can take, depending on planning priorities, schemes, models, and efficiency, depending on whether the process evaluates from a simple or a complex perspective.

Table 1. An understanding of informality through the lens of complexity.

\begin{tabular}{|c|c|c|c|c|}
\hline & 1970s/1980s & $1990 \mathrm{~s}$ & $2000 \mathrm{~s}$ & $2010 s$ \\
\hline Priorities & Permanent houses & $\begin{array}{l}\text { Areas fitting formal local } \\
\text { planning schemes }\end{array}$ & & \\
\hline $\begin{array}{l}\text { Efficiency from a } \\
\text { simple perspective }\end{array}$ & Low & High & High & High \\
\hline $\begin{array}{l}\text { Efficiency from a } \\
\text { complex perspective }\end{array}$ & High/experimentation & High/emergence & Low & Low \\
\hline Self-organisation & Forming/Storming & Norming/Performing & Performing & Performing \\
\hline Spatial models & Greater city & Metropolitan area & & \\
\hline Planning schemes & Local/regional & $\begin{array}{l}\text { Metropolitan spatial plan } \\
\text { Local land use plans }\end{array}$ & \multicolumn{2}{|c|}{$\begin{array}{l}\text { Metropolitan perspective (climate } \\
\text { change, risk mitigation, energy } \\
\text { efficiency) }\end{array}$} \\
\hline
\end{tabular}

Although informality is not seen as a problem in Portugal, many legal and technical tools have been developed, in order to give informal settlements a legal status. Even though great efforts have been made to guarantee high urban standards and a fair distribution of costs and benefits, they quite often become urban realities disconnected from planning schemes. The rare link between former informal settlements and planning schemes occurs at the regional level, while they tend to be ignored at the local level, when it comes to dealing with their spatial integration among other urban areas.

\section{The Case Study in Bandung and the Institut Teknologi Bandung-The University of Sydney Joint Studio}

Unlike Portugal, the educational attempts to deal with informality in Indonesia are affected by the visual, demographic, and economic omnipresence of kampongs, at least in major urban areas. Informality is an increasingly common phenomenon in a country representative of the so-called Global South, affecting everyday life. It combines unstoppable processes of informal occupation of land, which 
is predominantly land squatting [61]. Since 2017, the author has taken part in activities at the joint studio established by the University of Sydney and Institut Teknologi Bandung (TUS ITB). This joint initiative puts Australian students in direct contact with informality in the city of Bandung, focusing on the identification of adaptive and evolutionary patterns in the urban setting [52]. Two questions become obvious: What can this exchange of experiences bring to the setting? How can this lead to a different approach to informality in urban design education?

\subsection{Tamansari Valley, Bandung—West Java, Indonesia}

The discussion of the integration of informal areas into the urban system will be based on a recent experience dealing with the urban fabric of one kampong (a type of informal settlement) in Tamansari Valley in Bandung, West Java, Indonesia. It is a settlement that has recently run the risk of eviction. The settlement's urban fabric not only consolidated its shape over decades, occupying former rice field terraces, but also developed architectural features to meet residents' needs and constant negotiation between neighbours and other groups (from academia and local government).

The TUS ITB studio led by Prof. Paul Jones-focused on public spaces-looked mainly at different shapes of alleyways, interfaces between public and private spaces, textures and infrastructures. Analysis and field surveys led to the construction of a narrative starting with morphology, moving onto typology and ending with the analysis of adaptation processes. At the same time, they related to governance arrangements. Students provided analysis based on fieldwork while they collected data, summarising information, followed by more work after the end of the joint studio. Several publications explained its work and the outcomes of surveys, analysis and narratives [21,52]. Interestingly, students moved forward on measuring the pulse of the kampong, by registering subtle or more evident changes.

Residents experience the threat of eviction while Lebak Siliwangi is evolving and co-evolving with strong interaction with the city of Bandung.

\subsection{Detailed Analysis of the Joint Studio}

The joint studio started as part of the PLAN9049 International Urban Development Planning study unit [21]. As the joint studio's focus is on informal settlements in Bandung, the study unit was renamed Foundations of Informal Urbanism. It is a core study unit for the Master's in Urbanism—specialisation in Urban and Regional Planning and an elective unit for the Master's in Urban Design and the Master's in Urban and Regional Planning (62). This is the study unit within these three master programmes, where students have contact with urban informality [21].

The joint studio is part of a teaching process established in 2015, comprising preliminary field investigations, preparatory readings, studio—in country fieldwork, post-studio review—public exhibition and completion of a portfolio and individual reflection [21]. This entire programme established the basic structure for the following years in which the Joint Studio-In Country Fieldwork remained as a fixed part of the Foundations of Informal Urbanism study unit. Apart from The University of Sydney's academic and scientific body, together with the Institut of Teknologi of Bandung, it typically involves academics from ITB and other Indonesian academic institutions delivering lectures, professionals from Indonesia and abroad sharing their experiences, as part of government structures or private companies. Students work as local facilitators with former ITB planning students and residents in Tamansari. Additionally, students from ITB share the research undertaken for their own study units, focused on urban infrastructure in kampongs. The author of this paper was invited to join the first edition of the studio and participated between 2016 and 2019, delivering lectures, accompanying students in the studio and commenting upon and marking the outcomes of the 10-day joint studio.

Within this supportive context, the educational methods used in the 10-day studio include an initial guided visit of the site, and warmer/ice breaker activities that introduce students to the local context. It is worth mentioning that during the studio, not only do Indonesian students get to know Australian students, but Australian students also meet one another for the first time. Most of the time, students have lectures in the morning at the ITB and fieldwork in the afternoon. Visits to the 
community centres, which take part through local facilitators in discussions with residents, are also common. Personal contact with an increasing number of ITB student residents in the kampong during their academic studies has also become an important source of information, as they become "informal" facilitators. The proximity between the site and ITB (east of the kampong) and accommodation (on the west side) is crucial to student immersion-for instance, making short visits to the same places at different times of the day, like prayer times at the several mosques in the kampong.

Students' ability to grasp the key features of the kampong depends mostly on their profiles. Students' backgrounds vary in terms of professional experience, academic background, and national origin (a significant number are international students). This combination of profiles provides the studio with a diversity of perspectives and insights. Also, their motivations differ, coming from different post-graduate courses (urban and regional planning, urbanism and urban design). For some, this is an opportunity to gain overseas experience during their course, while for others there is a clear intention to understand informal urbanism and to discover and explore developing countries, as part of the Global South.

The results of the course, which are based on the learning-by-doing process, have a clear impact on students' training. As referred to in the Unit of Study, "By the end of this unit of study you should have an understanding of the (i) key readings on the dimensions of informal urbanism, (ii) key policy themes of poverty, spatial justice, and environmental sustainability, (iii) tools to explore the nature of informal urbanism, including understanding patterns and types of urban form and structure and their adaptation and transformation at the local level, and (iv) cross-cultural considerations in planning and urban design" [62]. Students demonstrate an ability to achieve an understanding of these aspects by building a narrative over the data collected during the studio and embedding preliminary investigations and preparatory readings. Outcomes vary because of the variety of the educational methods and the abovementioned participant profiles. The "and so what?" question as a key aspect of their narrative floats in the air as students reach the last day and deliver their presentations. Their narratives vary according to their profiles and motivations in understanding adaptive processes of spaces, from alleyway to kampong level.

Accompanying the students in these five editions of the joint studio and taking part in various debates urged the author to reflect and reply to his own "and so what?" embedding his own reflections on the Global North experiences of informal settlements. What about urban interfaces between the formal and informal city? What does informality in the 1980s in Portugal and in present-day Indonesia have in common? The following sections will discuss and highlight some key ideas on this question.

\section{The Contribution of Informality to Planning and Design Education}

In this globalised world, in which mega-cities sprout alongside global economic growth, informality is somehow unexpectedly part of this atmosphere of prosperity. This happens after years or decades of war (e.g., the earlier examples of the Portuguese colonies). Not only are planners still trained in specific national contexts [24], but many planning issues are dealt with at a national (if not at local) level, while their origin is global. Today, city slums do not belong to a specific urban environment; they are slums of the world.

Sustainable Development Goals of the New Urban Agenda are linked to each other, which means that the SDG 11's inclusiveness, resilience and sustainability must be addressed, not only at local, but also at the global level. To deal with informality, local needs have to be addressed-however, we must be aware that they are the result of dynamics that extend beyond the local to the global. How can the quality of life be improved if the global economy depends on low salaries to compensate for the costs of the distance between production and markets? How can slums be reduced if people are being evicted from city centres, like in post-war Luanda [63], due to the massive global investments in real estate in the city centre? Structurally speaking, change occurs by intertwining these various levels. 


\subsection{Contributions to Urban Planning and Design Education}

This globalisation and informality meet only to recognise that informal settlements and slums are worldwide phenomena. Firstly, informality is not addressed as a result of economic globalisation. Many developing economies are based on extremely low salaries, only compatible in the current context with very low housing standards, including insecure property rights, unsafe shelter solutions (at building and neighbourhood levels). These aspects are difficult to address solely at the national level (sometimes at lower levels), even with world organisation help. Secondly, informality is not only the result of political, environmental, or budgetary crises. It is also a result of peace and growth, as it happens in developing contexts. In fact, countries where informality flourishes are at peace and experiencing economic growth. In this case, the gentrification of central urban areas is contributing to the expulsion of old residents to the periphery, where they can only find affordable houses on the informal market [63]. The more integrated these aspects are in future approaches, where the urban fabric is not only addressed as the result of physical form, the better students will be prepared for future planning and design challenges when it comes to informality.

Students expect to be able to (re)discover dynamics of urban and architectural rules, beyond either upgrading or eviction of informal settlements in three steps. More than the debate between one and the other, it will be important to see planners and designers—as a first step-discovering the hidden rules that keep apparently chaotic settlements on an even keel with themselves and the city. Instead of imposing static rules on informal settlements, they may be able to learn from day-to-day adaptation to the environment (the neighbourhood, the street within the neighbourhood, the city). The second step should concern assessing the possibility of moving from temporary and exceptional to permanent planning and design rules (noting that "permanent" is not a synonym of "static"), thus, allowing for evolution. The third step regards the reflection on how these new rules can influence general building and urban design codes.

\subsection{Co-Evolution between Formal and Informal}

Although they belong to two different spheres, both formal and informal dynamics are not totally independent. Despite evolving in a non-linear way, that evolution is often co-dependent. If planning institutions take certain measures, for instance prohibiting the sale of land to more than one person, to avoid informal land fragmentation, informal settlements might change their behaviour and look for alternative ways of continuing their informal path. This might require more technical and legal skills, which some informal settlements might not be able to acquire. Some might stagnate or disappear, while others might be able to acquire new qualities, and therefore, advance their activity by evolving. This process of co-evolution, already identified at the institutional/spatial level in specific contexts [17], is also a reality when it comes to neighbouring formal and informal spaces, as an expression of what planning tends to deny: The interaction of legal and illegal [4], and of formal and informal occupations.

In the Global North, many formalised informal settlements (excluding formalisation through eviction) did not lose all their characteristics (this is a quality of evolution, as an entity evolves, continuity is kept). Although formalised informal settlements do not lose all their characteristics, I would prefer to call them ex-informal (to distinguish them from other formal settlements). They correspond to patterns. In general, at the metropolitan level, they sit next to infrastructures, which can generate new centralities. Another characteristic that distinguishes ex-informal settlements is an "informal stigma", such as low-income, immigration, criminality and other features considered negative, despite becoming formalised. Planners and planning institutions (including political decisions) are the main drivers of this tendency. If differently educated, future planners can change this. 


\subsection{Beyond Physical and Functional Data}

In this context, are statistical demographics useful? Who are residents in informal areas? Who has arrived and who has left? Below the umbrella of one stable number are multiple variations at different paces: Hourly, daily, yearly.

One can discuss the combination of stable and dynamic elements towards balance at different scales. At the city of Bandung level, the ITB campus is the stable mark of a hundred-year-old academic institution, one of the most prestigious in Indonesia, special when compared with the surrounding formal and informal settlements in constant change over recent decades. While the campus keeps its identity, some students live in the nearby kampong, while others use the kampong as a case study for their learning processes at the infrastructure level, for instance [64].

The same applies to other levels. While the kampong is one of the most dynamic elements of the urban system, when considering the kampong as a sub-system itself, a balance exists between the most stable and the most dynamic elements (Figure 1). Among the most stable elements is topography (where all the urban fabric stands), religious and civic buildings, while the most dynamic include private businesses in pre-existing buildings (which change at a fast pace) and street vendors. When it comes to specific elements of the urban grid, such as alleyways, differences can still be perceived, from residential to business-oriented spaces. New features appear, such as recent works to implement a sewage network (an element of stability in the middle of informality), a clear sign of informal/formal interaction.

\begin{tabular}{|c|c|c|c|}
\hline & City & Kampong & Intra kampong \\
\hline+ stable & ITB & Religious institutions & Topography \\
\hline & & Political institutions & $\begin{array}{l}\text { Infrastructures } \\
\text { Residential spaces } \\
\text { (alleyways, intersections) }\end{array}$ \\
\hline & Interfaces & & \\
\hline 7 & Informal settlements & & $\begin{array}{l}\text { Business oriented spaces } \\
\text { (alleyways, intersections) }\end{array}$ \\
\hline$\stackrel{+}{+}$ & $\begin{array}{l}\text { Users } \\
\text { Formal settlements }\end{array}$ & Private businesses & Alleyways \\
\hline & Broader & $\langle>$ & Narrower \\
\hline
\end{tabular}

Figure 1. How to move on from a complexity perspective: A balance between stability versus scale, instead of formal versus informal-a rationale for planning and design education. ITB, Institut Teknologi Bandung.

\subsection{Traditional Urban Planning and Design Ways of Integrating Informality: Adaptation as the Last Choice}

Urban planning and design have been founded on standardised rules serving the Global South and Global North, to be applied to realities to which they were not necessarily well matched. In general, one of the tendencies involved applying models too literally, intending to create spaces that fitted into pre-established rules, instead of adapting rules to fit spaces. This worsened the mismatch between planning and actions and informal urbanisation patterns. In fact, by not making adaptability part of planning and design, planning practice reduced the sustainability of solutions for informality, aggravating spatial and social segregation.

In the case of Portugal, only in very exceptional circumstances were institutions malleable enough to implement adaptive solution regarding the integration of informality. However, although exceptional, those circumstances generated a shift in the relationship between formal and informal urban systems. That shift consisted of learning from interacting with each other, leading to self-organisation and co-evolutionary processes, making formality and informality converge into a single urban system. This learning process has contributed to more responsive planning systems, demonstrating that it 
is possible to formalise the informal without eviction. Informality can be a source of problems, as well as help create responsive options for the general planning system, by easing long bureaucratic procedures, for instance.

If the complex perspective were not enough to question the dichotomy between informality and formality, a recent factor has appeared. While informal settlements were formalised, it became clear that the way they evolved went beyond their legal status. A third pattern has appeared-ex-informal, which affects the traditional formal/informal dichotomy. Ex-informality is characterised by informal stigmatisation, despite recently acquired formal status, which can be critical for planning design (opportunity for regeneration beyond legal procedures).

Urban design intersects and tries to give answers to these questions, such as inclusiveness, helping to solve what neither planning nor architecture is capable of. In the early 1960s, informality was not part of urban design programmes. While the abandonment of city centres [65], new urban settlements' illegibility [66] and segregation caused by zoning [67] were subject to debate and criticism of the modern city, informal settlements were an abnormality, which necessarily involved eviction. The eviction was not a matter for discussion (that was more to do with how the eviction took place). By the early 1960s, research and teaching on urban design informal settlements was not part of planning and design education agendas.

Nowadays, when technology and communication induce growth, changes are rapid, difficult to follow, and even harder to predict. Their impact reflects on the setting of territorial development. A consequence of rapid change has been governments' inability to supply formal housing solutions. Academia trained generations of planners and designers to deal with contexts of centralised planning responses to contexts of (apparently) greater certainty, usually dealing with new realities as "business as usual".

While this happens, according to United Nations records, informal self-arrangements, structured at different degrees guarantee-housing supply to one billion people in the world. This is a fast-growing phenomenon in the Global South, but not completely new. In the last century, developed countries experienced similar situations of having to deal with this emergence of informality.

\section{Conclusions}

The aim of this paper has been to explore new possibilities for planning education, bearing in mind the need to prepare future planners for new global challenges, which includes the impact of informality on the urban world and the sustainability of the planet. The UN's Sustainable Development Goals set a new agenda for the coming years. While business as usual risks increasing spatial segregation, this paper aims to inspire new planning paradigms and a new planning agenda to help students face this and other challenges, as future practitioners or academics.

Considering that peripheral problems tend to have more creative and less institutional responses, informality has been used in this paper to propose a new planning approach, in order to avoid eviction (most common in the Global South), as well as planning games that just legitimise the formalisation of informal settlements (such as recurrent amnesties, which are very popular in the Global North). The lessons from revisiting the development of Lebak Siliwangi, near the Institut of Teknologi of Bandung, were crucial to this reflection. In addition, awareness of the consequences of 30 years of formalisation of informal settlements in Global North regions was beneficial to this research. Although different contexts inspire different approaches, a common feature emerges. No matter how radical the solution adopted to formalise informal settlements, the segregation between formal planning actions and emergent ex-informal settlements prevails. Even in the most successful cases, planning scales tend to differ in their approach (and the closer they are to the "object", the more they tend to deny it).

Viewing the city as a system helps direct attention away from objects (the focus of modernist planning and design) to relationships between elements of the system. Moreover, recognising the complexity of the system helps move the planning focus away from the settlements' legal or illegal status to the role they play in the balance between stable and dynamic elements within each urban 
system. This new and less explored approach can lead to rethinking urban rules, not only when dealing with informal settlements, but also when responding to the need to improve planning rules to deal with spatial segregation in urban contexts in general.

To do so, this paper has addressed informality from a complexity perspective. Attempts to change the mindset are as important for planning in the present as in the past, with the introduction of the concept of mixed-use-mixed-hierarchy in the urban discourse, influencing it in an unprecedented way. This path has led to the introduction of new concepts in planning and design, such as the one of mixed-use, but has not had a strong influence on how planning rules kept being designed-focused on objects.

The results show that when confronted with a more diverse set of aspects regarding the urban fabric, rather than form over the background, students develop a better understanding of complexity. Dealing with informality exposes students to more challenging contexts [52]. As future practitioners, this is a step forward to the evolution of planning institutions, in the sense that planning institutions not only have to deal with informality, they also can learn from informality, through co-evolutionary processes.

In general, these changes are connected to the need to refresh a set of concepts that are often misleading for future planning and design professionals. Part of the effort to prepare students for global challenges involves the reinterpretation of these concepts. A key piece of planning systems is the whole of planning institutions. Ideas discussed in this paper underline the fact that planning institutions are not just monolithic bodies within public administration. They are heterogeneous, be it about their mission—regulatory or executive-or about their territorial scope. If public administration students are quite often aware of this institutional characteristic, the same hardly applies to planning and design students. Using a simplistic interpretation, this is a weakness of planning institutions, as it can reveal different ways of addressing planning and design problems. However, from a complex perspective, this is a quality, since it shows the malleability that allows either temporary or permanent adaptation.

Funding: This research received no external funding.

Conflicts of Interest: The author declares no conflict of interest.

\section{References}

1. Nel, D.; Du Plessis, C.; Landman, K. Planning for dynamic cities: Introducing a framework to understand urban change from a complex adaptive systems approach. Int. Plan. Stud. 2018, 23, 250-263. [CrossRef]

2. Rauws, W. Embracing Uncertainty without Abandoning Planning. disP Plan. Rev. 2017, 53, 32-45. [CrossRef]

3. Baumgart, S.; Kreibich, V. Informal Urbanization-Historical and Geographical Perspectives. disP Plan. Rev. 2011, 47, 12-23. [CrossRef]

4. Silva, P. Infrastructures and Urban Development: Discontinuities, Design and Planning; UniBo Press: Bologna, Italy, 2014.

5. Tumini, I.; Poletti, A. Natural disaster and informality (re)production in Chile. City Cult. Soc. 2019, 19, 100312. [CrossRef]

6. Carmon, N. Three generations of urban renewal policies: Analysis and policy implications. Geoforum 1999, 30, 145-158. [CrossRef]

7. Roy, D.; Lees, M. Understanding resilience in slums using an agent-based model, Computers. Environ. Urban Syst. 2020, 80, 101458. [CrossRef]

8. Fernandes, E. General considerations on the public policy of regularization of informal settlements in Latin America. Eure 2008, 34, 25-38.

9. Alexander, C. A City Is Not a Tree: 50th Anniversary Edition; Sustasis Press and Center for Environmental Structure: Portland, OR, USA, 2015.

10. Dawes, M.J.; Ostwald, M.J. Christopher Alexander's A Pattern Language: Analysing, mapping and classifying the critical response. City Territ. Archit. 2017, 4, 17. [CrossRef]

11. Park, Y.; Newman, G.D. A framework for place-making using Alexander's patterns. City Territ. Archit. 2017, 4, 17. [CrossRef]

12. Marshall, S. City Design and Evolution; Routledge: London, UK; New York, NY, USA, 2009. 
13. Batty, M. Cities and Complexity, Understanding Cities with Cellular Automata, Agent-Based Models, and Fractals; MIT Press: Cambridge, UK, 2007.

14. De Roo, G.; Rauws, W.S. Positioning Planning in the World of Order, Chaos and Complexity: On Perspectives, Behaviour and Interventions in a Non-linear Environment. In Complexity Theories of Cities Have Come of Age; Portugali, J., Meyer, H., Eds.; Springer: Berlin/Heidelberg, Germany, 2012.

15. Heylighen, F. Complexity and Self-Organization. In Encyclopedia of Library and Information Sciences; Bates, M., Maack, M., Eds.; Taylor \& Francis: Abingdon, UK, 2008.

16. Davy, B. Polyrational property: Rules for the many uses of land. Int. J. Commons 2014, 8, 472. [CrossRef]

17. Silva, P.; Farrall, H. Lessons from informal settlements: A 'peripheral' problem with self-organising solutions. Town Plan. Rev. 2016, 87, 297-319. [CrossRef]

18. Dovey, K.; Cook, B.; Achmadi, A. Contested riverscapes in Jakarta: Flooding, forced eviction and urban image. Space Polity 2019, 23, 265-282. [CrossRef]

19. Odendaal, N.; Watson, V. Partnerships in Planning Education: The Association of African Planning Schools (AAPS); The Urban Book Series; Springer: Cham, The Netherlands, 2018.

20. Siame, G. The value and dynamics of community-based studio projects in planning education in the Global South. Berkeley Plan. J. 2016, 28, 40-67. [CrossRef]

21. Jones, P. Unpacking Informal Urbanism: Urban Planning and Design Education in Practice; ITB University Press: Bandung, Indonesia, 2016.

22. World Bank. Indonesia-National Slum Upgrading Project (English); World Bank Group: Washington, DC, USA, 2016.

23. Cardoso, R. Desenraizar o ordenamento: Território, Planeamento e Urbanismo na pós-colonialidade portuguesa. Territ. Planeam. Urban. 2018, 1, 30-61.

24. Alterman, R. From a Minor to a Major Profession: Can Planning and Planning Theory Meet the Challenges of Globalisation? Trans. AESOP 2017. [CrossRef]

25. AESOP-Association of European Schools of Planning. Available online: http://www.aesopplanning.eu/ (accessed on 4 October 2019).

26. ACSP-Association of Collegiate Schools of Planning. Available online: https://www.acsp.org/ (accessed on 4 October 2019).

27. APSA-Asian Planning Schools Association. Available online: http://apsaweb.org/ (accessed on 4 October 2019).

28. AAPS-Association of African Planning Schools. Available online: https://www.africanplanningschools.org. $\mathrm{za} /$ (accessed on 4 October 2019).

29. Secchi, B. Diary 11 | the Form of the City, Planum Magazine. Available online: http://www.planum.net/diary11-the-form-of-the-city-bernardo-secchi (accessed on 16 September 2019).

30. Van Welie, M.; Truffer, B.; Gebauer, H. Innovation challenges of utilities in informal settlements: Combining a capabilities and regime perspective. Environ. Innov. Soc. Transit. 2019, 33, 84-101. [CrossRef]

31. Kim, H.; Yoon, Y.; Mutinda, M. Secure land tenure for urban slum-dwellers: A conjoint experiment in Kenya. Habitat Int. 2019, 93, 102048. [CrossRef]

32. Bardhan, R.; Sunikka-Blank, M.; Haque, A.N. Sentiment analysis as tool for gender mainstreaming in slum rehabilitation housing management in Mumbai, India. Habitat Int. 2019, 92, 102040. [CrossRef]

33. Carrasco, S.; Dangol, N. Citizen-government negotiation: Cases of in riverside informal settlements at flood risk. Int. J. Disaster Risk Reduct. 2019, 38, 101195. [CrossRef]

34. Attia, S.; Ibrahim, A.A.A.M. Accessible and Inclusive Public Space: The Regeneration of Waterfront in Informal Areas. Urban Res. Pract. 2018, 11, 314-337. [CrossRef]

35. Sudhipongpracha, T.; Dahiya, B. City Profile: Khon Kaen, Thailand. Environ. Urban. Asia 2019, 10, $271-289$. [CrossRef]

36. Jones, P. The case for inclusion of international planning studios in contemporary urban planning pedagogy. Sustainability 2019, 11, 4174. [CrossRef]

37. Winkler, T. At the Coalface: Community-University Engagements and Planning Education. J. Plan. Educ. Res. 2013, 33, 215-227. [CrossRef]

38. Beavon, K.S.O. Mexico City and Colonias populares: Hints for a South African squatter policy. S. Afr. Geogr. J. 1989, 71, 142-156. [CrossRef] 
39. Unece-United Nations Economic Commission for Europe. Formalizing the Informal: Challenges and Opportunities of Informal Settlements in South-East Europe; United Nations: New York, NY, USA; Geneva, Switzerland, 2015; ISBN 978-87-92853-31-8.

40. Unece-United Nations Economic Commission for Europe. Self-Made Cities: In Search of Sustainable Solutions for Informal Settlements in the United Nations Economic Commission for Europe region; United Nations: New York, NY, USA; Geneva, Switzerland, 2009; ISBN 978-92-1-117005-4.

41. Salingaros, N. Adaptive versus random complexity. New Des. Ideas 2018, 2, 51-61.

42. Fuchs, C. Co-operation and self-organization. Triple C 2003, 1, 1-52. [CrossRef]

43. Holling, C.S.; Gunderson, L.; Peterson, G. Sustainability and Panarchies. In Panarchy: Understanding Transformations in Human and Natural Systems; Gunderson, L., Holling, C., Eds.; Island Press: London, UK, 2002; pp. 25-62.

44. Prigogine, I.; Stengers, I. Order out of Chaos: Man's New Dialogue with Nature; Bantam Books: New York, NY, USA, 1984.

45. Ostrom, E. Understanding Institutional Diversity; Princeton University Press: Princeton, NJ, USA, 2005.

46. Chiodelli, F.; Moroni, S. The complex nexus between informality and the law: Reconsidering unauthorised settlements in light of the concept of nomotropism. Geoforum 2014, 51, 161-168. [CrossRef]

47. Rosner-Manor, Y.; Borghini, S.; Boonstra, B.; Silva, P. Adaptation of the urban codes-A story of placemaking in Jerusalem. Environ. Plan. B Urban Anal. City Sci. 2019. [CrossRef]

48. Salingaros, N.A. Biophilia and Healing Environments; Terrapin Bright Green LLC: New York, NY, USA, 2016.

49. Tvedten, I.; Candiracci, S. "Flooding our eyes with rubbish": Urban waste management in Maputo, Mozambique. Environ. Urban. 2018, 30, 631-646. [CrossRef]

50. Cherunya, P.C.; Ahlborg, H.; Truffer, B. Anchoring innovations in oscillating domestic spaces: Why sanitation service offerings fail in informal settlements. Res. Policy 2020, 49, 103841. [CrossRef]

51. Wagner, M. Evading spatial planning law-Case study of Poland. Land Use Policy 2016, 57, 396-404. [CrossRef]

52. Jones, P. Formalizing the Informal: Understanding the Position of Informal Settlements and Slums in Sustainable Urbanization Policies and Strategies in Bandung, Indonesia. Sustainability 2017, 9, 1436. [CrossRef]

53. Calor, I.; Alterman, R. When enforcement fails: Comparative analysis of the legal and planning responses to non-compliant development in two advanced-economy countries. Int. J. Law Built Environ. 2017, 9. [CrossRef]

54. Silva, P.; Farrall, H. From Informal to Formal: What Can Be Learned from Reviewing 50 Years of Portuguese Models, Policies and Politics. In Dynamics and Resilience of Informal Areas: International Perspectives; Springer: Berlin/Heidelberg, Germany, 2016.

55. Parbhoo, A.; Louw, Q.A.; Grimmer-Somers, K. Burn prevention programs for children in developing countries require urgent attention: A targeted literature review. Burns 2010, 36, 164-175. [CrossRef] [PubMed]

56. Wind, B.; Ibrahim, B. The war-time urban development of Damascus: How the geography-and political economy of warfare affects housing patterns. Habitat Int. 2020, 96, 102109. [CrossRef]

57. López-Morales, E.; Pineda, P.F.; Ramos, H.O. Immigrants in settlements in Chile: A mechanism of integration or the effect of exclusion? Rev. INVI 2018, 33, 159-185.

58. Grashoff, U. Cautious occupiers and restrained bureaucrats: Schwarzwohnen in the German Democratic Republic. Somewhat different from squatting. Urban Stud. 2019, 56, 548-560. [CrossRef]

59. Silva, P. Designing urban rules from emergent patterns: Co-evolving paths of informal and formal urban systems-The case of Portugal. IOP Conf. Ser. Earth Environ. Sci. 2018, 158, 012001. [CrossRef]

60. Antonić, B.; Djukić, A. The phenomenon of shrinking illegal suburbs in Serbia: Can the concept of shrinking cities be useful for their upgrading? Habitat Int. 2018, 75, 161-170. [CrossRef]

61. Obermayr, C. Introduction to Indonesia. In Sustainable City Management; The Urban Book Series; Springer: Cham, The Netherlands, 2017.

62. The University of Sydney. Unit of Study Descriptions. Available online: http://sydney.edu.au/handbooks/ architecture/postgraduate/coursework/urban_design_unit_of_study_descriptions.shtml (accessed on 12 January 2020).

63. Buire, C. Intimate Encounters with the State in Post-War Luanda, Angola. J. Dev. Stud. 2018, 54, 1-17. [CrossRef] 
64. Suryani, N.; Ichiki, A.; Shimizi, T.; Maryati, S. Investigation of the Water Supply System and Water Usage in Urban Kampung of Bandung City, Indonesia. J. Water Environ. Technol. 2019, 17, 375-385. [CrossRef]

65. Jacobs, J. The Death and Life of Great American Cities; Vintage: New York, NY, USA, 2016.

66. Lynch, K. The Image of the City; MIT Press: Cambridge, UK, 1964; ISBN 9780262620017.

67. Alexander, C. A Pattern Language; Oxford University Press: New York, NY, USA, 1977.

Publisher's Note: MDPI stays neutral with regard to jurisdictional claims in published maps and institutional affiliations.

(C) 2020 by the author. Licensee MDPI, Basel, Switzerland. This article is an open access article distributed under the terms and conditions of the Creative Commons Attribution (CC BY) license (http://creativecommons.org/licenses/by/4.0/). 